\title{
BIOADSORPTION OF HEAVY METALS FROM THE PHARMACEUTICAL EFFLUENTS, CONTAMINATED SOILS AND WATER BY FOOD AND AGRICULTURAL WASTE: A SHORT REVIEW
}

\author{
P. Ziarati ${ }^{1 *}$, D. Moradi ${ }^{1}$, V. Vambol ${ }^{2}$ \\ ${ }^{1}$ Nutrition and Food Sciences Research Center, Tehran Medical Sciences, Islamic Azad University, Tehran, Iran \\ 2Public Agency "National Scientific and Research Institute of Industrial Safety and Occupational Safety and Health", Kiev, Ukraine \\ *Corresponding email: ziarati.p@iaups.ac.i
}

Received: 11 May 2020; Accepted; 8 June 2020

Cite as: Ziarati, P., Moradi, D., Vambol, V. (2020). Bioadsorption of heavy metals from the pharmaceutical effluents, contaminated soils and water by food and agricultural waste: a short review. Labour Protection Problems in Ukraine, 36(2), 3-7.

Soil and water resources pollution by heavy metals, specially originated from anthropogenic sources, as a result of their toxicity ramification on human health, has been known as a major and serious environmental problem for last few decades. Particularly relevant is the problem of pharmaceutical wastewater, as this wastewater contains active pharmaceutical ingredients and a wide range of heavy metals. In the same time the food waste is commonly produced in all the steps of food life cycle, such as during agricultural production, industrial manufacturing, processing and distribution and even consumer-generated in the context of private households. Mostly they have high-value components such as phytochemicals, proteins, flavour compounds, polysaccharides, fibers, and which can be re-used as nutraceuticals and functional ingredients. The research aim is to study the potential of food and agricultural waste to remove heavy metals from contaminated water and soil. The study the potential of food and agricultural waste to remove heavy metals from contaminated water and soil was conducted on the basis of open scientific sources. Scientific sources were selected by keywords no later than 2003 or with high citation value. Bio-sorption is a relatively new process that has proven very promising for the removal of heavy metals from wastewater. Due to the higher affinity of the adsorbent for the adsorbate species, the latter is attracted and bound there by different mechanisms. The process continues till equilibrium is established between the amount of solid-bound adsorbate species and its portion remaining in the solution. The feasibility of using an adsorbent is based on the cost of the bio sorbent has to be optimum, as they often are made from abundant or waste material. Peel of citrus and pomegranate, vegetables peel, fruit pit shell, tea and herbal tea waste and agricultural waste mix demonstrate great potential as bio-adsorbent.

Keywords: heavy metals; bio-adsorption process; agricultural waste; disposal; environment.

\section{БІОАДСОРБЦІЯ ВАЖКИХ МЕТАЛІВ ІЗ ФАРМАЦЕВТИЧНИХ СТОКІВ, ЗАБРУДНЕНИХ ҐРУНТІВ І ВОДИ ХАРЧОВИМИ ТА СІЛЬСЬКОГОСПОДАРСЬКИМИ ВІДХОДАМИ: КОРОтКИЙ ОгляД}

\author{
П. Зіараті ${ }^{*}{ }^{*}$, А. Мораді ${ }^{1}$, В. Вамболь ${ }^{2}$
}

${ }^{1}$ Науково-дослідний центр харчування та харчових наук, Тегеранські медичні науки, Ісламський університет Азад, Тегеран, Іран ²Державна установа «Національний науково-дослідний інститут промислової безпеки та охорони праці», Київ, Україна

*E-mail для листування: ziarati.p@iaups.ac.

Отримано: 11 Травня 2020; Прийнято: 8 Червня 2020

Цитувати як: Ziarati, P., Moradi, D., Vambol, V. (2020). Bioadsorption of heavy metals from the pharmaceutical effluents, contaminated soils and water by food and agricultural waste: a short review. Labour Protection Problems in Ukraine, 36(2), 3-7.

Забруднення грунтових і водних ресурсів важкими металами, у тому числі унаслідок антропогенної дії, і як результат їх токсична дія на здоров'я людини, є серйозною екологічною проблемою останніх десятиліть. Особливо актуальною є проблема фармацевтичних стічних вод, оскільки вони містять активні фармацевтичні інгредієнти і широкий спектр важких металів. У той же час харчові відходи зазвичай утворюються на всіх етапах життєвого циклу продуктів харчування, а саме: в сільськогосподарському виробництві, промисловому виробництві, при переробці та розподілі, і навіть у приватних домогосподарствах. В основному харчові відходи містять цінні компоненти (фітохімічні, білки, смакові з'єднання, полісахариди, волокна), які можуть бути повторно використані як нутрицевтики і функціональні інгредієнти. Мета дослідження - вивчити потенціал харчових і сільськогосподарських відходів для видалення важких металів із забрудненої води і грунту. Дослідження потенціалу харчових і сільськогосподарських відходів для видалення важких металів із забрудненої води і грунту проводилося на основі відкритих наукових джерел, які були відібрані за ключовими словами, в часовому інтервалі починаючи з 2003 року або 3 високою цитованістю. Біосорбція є відносно новим процесом, який виявився дуже перспективним для видалення важких металів із стічних вод. Через більш високу спорідненість адсорбенту до адсорбату, останній притягується і зв'язується там різними механізмами. Процес продовжується доти, поки не буде встановлено рівновагу між кількістю твердих часток адсорбата і його частиною, що залишається в розчині. Доцільність використання адсорбентів заснована на тому, що вартість біосорбента має бути оптимальною, оскільки вони часто виготовляються 3 відходів, що постійно утворюються у великій кількості, такого як: шкірка цитрусових і граната, шкірка овочів, дерев'яниста оболонка фруктового ядра, відходів чаю і трав'яного чаю, суміш сільськогосподарських відходів, що демонструють великий потенціал у якості біосорбенту

Ключові слова: важкі метали; процес біоадсорбції; сільськогосподарські відходи; утилізація; довкілля.

1. Problem statement and analysis of the recent researches and publications.

Growth of various industries in the world wide has caused soils and water resources pollution $[1,2]$. A lot of research has been done to find ways to decontamination wastewater. On the other hand, soil contamination by heavy metals, specially originated from anthropogenic sources [3-5], as a result of their toxicity ramification on human health, has been known as a major and serious environmental problem for last few decades. Particularly relevant is the problem of pharmaceutical wastewater, as this wastewater contains active pharmaceutical ingredients and a wide range of heavy metals [6-8]. 
In the same time the food waste is commonly produced in all the steps of food life cycle, such as during agricultural production, industrial manufacturing, processing and distribution and even consumer-generated in the context of private households [9-11]. Mostly they have high-value components such as phytochemicals, proteins, flavour compounds, polysaccharides, fibers, and which can be reused as nutraceuticals and functional ingredients.

In the same time the food waste is commonly produced in all the steps of food life cycle, such as during agricultural production, industrial manufacturing, processing and distribution and even consumer-generated in the context of private households. Mostly they have high-value components such as phytochemicals, proteins, flavour compounds, polysaccharides, fibers, and which can be re-used as nutraceuticals and functional ingredients.

Dead biomass is particular economic interest, highly efficient, low cost and easily ecofriendly and available adsorbents of heavy metals. Although various nutshell powders as agricultural waste materials have been used for centuries in folk medicine, in many countries nowadays is known in the act of profitable and ecofriendly renewable, unique chemical composition, abundant availability, economical and simply organized is seem to be applicable option for heavy metal remediation.

Thus, the research aim is to study the potential of food and agricultural waste to remove heavy metals from contaminated water and soil.

\section{Statement of the problem and its solution.}

\subsection{Materials and methods.}

The study the potential of food and agricultural waste to remove heavy metals from contaminated water and soil was conducted on the basis of open scientific sources. Scientific sources were selected by keywords no later than 2003 or with high citation value.

\subsection{Results and Discussion.}

\subsubsection{Peel of citrus and pomegranate.}

According to scientific research as bio-adsorbents, citrus peel and pomegranate peel deserve great attention. Pomegranate peel and orange waste usually cause environmental problems and previously studies distinguished that they have no economic value for food industries [12]. Ververi and Goula in 2019 used non-modified pomegranate peel and orange juice by-product, as biosorbents for removal of phenolic compounds from olive-mill wastewater (OMW) [13]. In this study they used two main steps for preparation adsorbent. In the first step, pomegranate peel and orange waste were dried and milled, and then their own phenolic contents were removed by ultrasound-assisted extraction. In the second step the free phenolic samples as adsorbent with OMW solution were agitating in rotary shaker, then filtered and analyzed for residual total phenols. Finally, the adsorbent and OMW solution separated using centrifuge and dried again, then the desorption process percentage of phenolics was calculated. They found that the adsorption efficiency of pomegranate peel slightly higher than orange juice byproduct, and it may because of the presence of fiber content much higher than orange waste, also chemical composition of pomegranate peel. Generally, adsorption equilibrium of phenolic compounds for both bio-sorbents reached after about $20 \mathrm{~min}$ of contact and longer contact time had no positive effect on adsorption.

\subsubsection{Vegetables peel.}

In 2018 Stavrinou et al. used the bananas, cucumbers and potatoes peels as bio-sorbent to remove cationic, namely Methylene blue (MB) and anionic, namely Orange G (OG) dyes from aqueous solutions [14]. Their results showed that the MB removal efficiency of the wastes was much more than OG removal efficiency. In other words, in the case of anionic dyes no considerable bio-sorption on the surface of biosorbents was observed. The reason for this difference in adsorption demonstrated the assumption about the main mechanism of bio-sorption. Based on this assumption, electrostatic attraction of dye ions to the charged surface sites of adsorbents is the main mechanism of adsorption. Maximum adsorption reached after 4 hours. The rate of adsorption in both of them was similar, in the first $30 \mathrm{~min}$ the adsorption capacity increased rapidly and its related to strong attractive forces between dye molecules and adsorbent because at the initial, multitudinous functional groups were attendance on the surface of all bio-sorbents.

The usage of banana peel as bio-sorbent for removing Cadmium and Lead from Oryza sativa rice was determined by Motaghi and Ziarati [15]. The collected peel of banana was subjected to three processes: powdered after drying, heated in 450 to obtained carbon active and treated by $1 \%$ citric acid. Then three above forms were analyzed for determination sufficiency as bio-sorbent. Results of this work improved the efficiency of modified waste of banana by $1 \%$ citric acid in removing heavy metal such as Cadmium and Lead from rice. Its potential is relevance to the presence of functional groups in the agricultural waste, insomuch this functional groups have the affinity for metal complexation. The application of sour lemon peel (SPL) as bio-sorbent for removing heavy metal from Oryza sativa Rice was published by Razafsha et al. in 2016 [16]. They were utilized sour lemon peel in three forms: dried powder of sour lemon peel, as activated carbon by heated the SPL in 400 and the third one treated peels by $1 \% \mathrm{v} / \mathrm{w}$ phosphoric acid. The samples were separately placed in plastic tank containing distilled water, salt and rinsing rice at specific $\mathrm{pH}$, temperature and contact time $(10,15,20,30$ minutes and 1 hour). Finally, the absorption of Nickel, Cadmium and Lead from rice samples into sorbent (SPL powder) was measured. Based on their published data, the sour lemon peels have a good potential for adsorption Nickel, Cadmium and Lead from rice, also cooking rice by soaking rinsed rice samples by $\mathrm{NaCl}$ $2 \%$ and sour lemon peel modified by phosphoric acid $1 \%$ at least for 1 hour had the greatest effect.

\subsubsection{Fruit pit shell.}

In slightly similar studies, the other researcher was used agricultural waste in removing heavy metals. In 2018 Tavakolihosseinabady et al. indicated the adequate effect of apricot pit shell on detoxification of heavy metals from leafy edible vegetables [17]. They were successful in removing Lead, Nickel and Cadmium from edible vegetables. In 2018, Ziarati and Hochwimmer used hard shell of domestic wild almond; Amygdalus lycioides and Amygdalus wendelboi, for removing nitrate from root and leafy vegetables such as Iceberg and Romani Lettuce, Carrot, Celery, Potato, Cabbage, Broccoli, Eggplant, Cauliflower and Chinese cabbage [18]. They recommended the best efficient contact time for treated vegetables by powder of wild almond shell was $15 \mathrm{~min}$, although $20 \mathrm{~min}$ was more worked. As well as, addition of almond shell, even different concentration of shell as adsorbent did not impress or change the sensory attributes or $\mathrm{pH}$ of samples. Generally, A. lycioides and A. wendelboi were more effective in decrease nitrate and nitrite contents from most vegetables in this study, particularly iceberg and Romania lettuce samples and carrot samples.

In 2016 Ziarati and colleagues used the modified shell of two species of wild endemic almond (Amygdalus lycioides and Amygdalus wendelboi) as adsorbent for removal of heavy metal ions such as $\mathrm{Ni}^{2+}, \mathrm{Cr}^{6+}$ and $\mathrm{Cr}^{3+}$ from contaminated water [19]. They used phosphoric acid $2 \%$ to modify the shells of wild almond. According to their finding, the removal capacity 
of heavy metal ions was increased with an increase in the dose of both adsorbents and their contact time, also in the case of chrome the concentration of heavy metal in water (600 mg/kg of $\mathrm{Cr}(\mathrm{III})$ and also $\mathrm{Cr}(\mathrm{VI})$. Solution $\mathrm{pH}$ of 3.2 and 48 hours contact time was the optimum condition for maximal adsorption, but in this condition $A$. wendelboi showed the optimal ability against $A$. lycioides for adsorbing heavy metal.

\subsubsection{Tea and herbal tea waste.}

As the pharmaceutical residue and chemical materials from laboratories often poured into the sewer waste stream, it could increase the risk of leakage these materials to drinking water. Based on this problem, Pourzare and her colleagues in 2017, used the residues of Chamomile tea for removing Cadmium and Nickel Contents from pharmaceutical effluent [20]. The collected effluent by them was inducted to the soil samples after analyzed for any heavy metal. Then Basil that also analyzed for heavy metal was cultivated in the studied soil. Every 10 days up to 60 days, the effluent and plant analyzed for heavy metal. Their finally results demonstrated the efficiency of chamomile tea residue for adsorption of $\mathrm{Ni}$ and $\mathrm{Cd}$ in short time. As well as the concentration of chamomile in the polluted soil influenced on the adsorption rate of heavy metal too. The effective contact time was 20 days that the highest adsorption capacity was observed.

The results of experimental study by Ziarati et al. [21] revealed that using $0.5 \%$ red tea residue in accompany by $3 \%$ black tea residue can remove and decrease Cadmium and Nickel significantly and for Cobalt decreasing the rate of adsorption is not as much as 2 other metals but remove Cobalt after 40 minutes in remarkable contents. Next, mathematical modelling was carried out based on experimental data. Work on the mathematical model creation was divided into several stages. At the first stage, the general kinetic regularities of the adsorption process were assessed. At the second stage, model coefficients specific values were assessed. At the third stage, the technological parameters impact on technological solutions was assessed. Next, mathematical modelling was carried out based on experimental data. Work on the mathematical model creation was divided into several stages. At the first stage, the general kinetic regularities of the adsorption process were assessed. At the second stage, model coefficients specific values were assessed. At the third stage, the technological parameters impact on technological solutions was assessed [22].

\subsubsection{Agricultural waste mix}

Prasath et al. in 2014 used agricultural waste as adsorbent for removal Acid Blue 92 (AB92) dye from aqueous solution [23]. They prepared activated carbons of Eichornea crasssipes (EC), Sugarcane bagasse (SB), Tea waste (TW) and Guava leaf (GL) as sorbent [23]. They evaluated the effect of adsorbent dosage, $\mathrm{pH}$, contact time and an initial dye concentration on the removal capacity. According to the data of this literature the percentage removal is directly related to contact time, initial $\mathrm{pH}$ and dose, vice versa have redirect relationship with an initial concentration and particle size. Their results implicated the efficiency of the foregoing agricultural waste as sorbent for depollution water, wastewater and any solution polluted with dye material. Previously, researchers have confirmed that there is an increase in risk of cancers (bladder, liver, kidney and skin) and severe diarrhea in human body due to the presence of $\mathrm{Cr}$ species in drinking water. That's why; Fan et al. (2016) tried to elimination $\mathrm{Cr}$ from aqueous solution [24]. In this research, they used rice husk to preparing the magnetic adsorbent by carbon-thermal method. The photoelectron peak of $\mathrm{Cr}$ as results of wide-scan XPS characterization were elucidated the uptake of $\mathrm{Cr}$ on the sorbent. Overall the waste RH-derived magnetic carbon adsorbent implemented good magnetic separation by its porous structure and high surface area. Rice husk is the outer protective layer of the grains rice, which made of lignin and opaline silica [25]. Through the processing of rice, the husks will be removed as a waste of process [26]. The efficiency of natural rice husk as sorbent was studied by Subramaniam et al. (2004). They indicated the potential of untreated rice husk for removing heavy metal at $\mathrm{pH}$ value 2 , in this $\mathrm{pH} 66 \%$ of $\mathrm{Cr}(\mathrm{VI})$ was removed [27]. Another study about uptake heavy metal from aqueous solutions, is the work that conducted by Wong et al. in 2003. They used the modified rice husk by tartaric acid as sorbent [28]. Based on their founding, the highest adsorption of Lead and Copper was when the $\mathrm{pH}$ value increased from 2 to 3 and after this range its remained comparatively constant. In 2003, Ajmal et al. determined the adsorption capacity of several heavy metals such as $\mathrm{Ni}$ (II), $\mathrm{Zn}(\mathrm{II}), \mathrm{Cd}(\mathrm{II})$, and $\mathrm{Cr}(\mathrm{VI})$ by untreated and phosphate treated rice husk [29]. It was reported that in the presence of phosphate treated rice husk the adsorption of $\mathrm{Ni}$ and $\mathrm{Cd}$ were increased, but the adsorption of $\mathrm{Cd}$ was affected by contact time, concentration, temperature, adsorbent doses and $\mathrm{pH}$ of the solution. Overall, the most effective $\mathrm{pH}$ was found to be 12 for all of them [30].

Extracted the hulls of soybean with $\mathrm{NaOH} 0.1 \mathrm{~N}$, then modified with different concentration of citric acid from 0.1 to 1.2 $\mathrm{M}\left(120^{\circ} \mathrm{C}\right.$, for 90 minutes $)$. Their results indicated the potential of modified soybean hull as sorbent for uptake heavy metals. They showed that the modified skin was more effective than unmodified, which adsorption of $\mathrm{Cu}^{2+}$ by modified hull was 0.68 to $2.44 \mathrm{~m}$ moles $/ \mathrm{g}$, but unmodified was $0.39 \mathrm{~m}$ moles per $\mathrm{g}$ of hulls. Also the best concentration of citric acid for modified soybean hull was $0.6 \mathrm{M}$ and above, which per gram of modified hull at this concentration removed $1.7 \mathrm{~m}$ moles Copper ions from solution and its due to increasing the amount of carboxyl group on the soybean skins. Quek et al. compared the sorption capacity for Lead and Copper by Sago waste. In their study sago waste was used to absorption heavy metal from solution [31]. They demonstrated that $\mathrm{pH}$ at the range of 4 to 5.5 leads to best results. The fitted of equilibria data with Langmuir constants, showed the higher sorption capacity for $\mathrm{Pb}$ than $\mathrm{Cu}$ by Sago waste sorbent, $46.6 \mathrm{mg} / \mathrm{g}, 12.4 \mathrm{mg} / \mathrm{g}$, respectively. Also rice husk was used as sorbent for removing toxic metals from waste water. According to the results were published by Munaf and Zein [32]. The percentage removal of Chromium, Zinc, Copper and Cadmium ion at optimal conditions, was $79 \%, 85 \%, 80 \%$ and $85 \%$ respectively. Marshall and his colleagues studied the potential of several agricultural by-products as sorbent for absorption $\mathrm{Zn}$ (II) ions from aqueous solutions such as soybean and cottonseed hulls, rice straw and sugarcane bagasse [33]. The highest adsorption capacity in this literature was belonged to soybean hulls, ulterior cottonseed hulls and sugarcane bagasse had least capacity following rice straw. The potential of dyestuff-treated rice husk for uptake heavy metal from waste water was considered by Suemitsu et al. [34].

In dyestuff-treated rice husk, the rice was coated with the reactive dye of Procion Red or Procion Yellow. The yellow dye stuff-treated husk uptake all existing contents of the Lead in the ambient $(100 \%)$. Following Lead, Mercury has the highest amount of absorption by yellow dyestuff-treated husk. About red dyestuff-treated husk the high removals were observed on Lead(II) and Cadmium(II) at $99.8 \%$ and $99.2 \%$ respectively. Adsorption behaviour of heavy metals on dyestuff-treated rice husk was proved the removal capacity of heavy metal ions from aqueous solution by treated husk.

The relationship between contact time and the percentage removal of heavy metals from groundwater with eucalyptus carbon powder was studied at a room temperature at intervals 
from 30 minutes to 3 hours. The percentage of adsorption was found to increase continually with time till the equilibrium is attained with saturation at $180 \mathrm{mins}$. The percentage reduction of Copper from 27 to 84, Chromium from 75 to 83, Lead from 11 to 79 and Manganese from 43 to 83 for adsorbent of eucalyptus carbon powder has slightly increased. Due to utilization of active sites is larger surface area, the percentage reduction of Cadmium from 36 to 72 , had a decreased adsorption efficiency and less adequate availability of active sites on the adsorbents. Steep reduction of Copper percentage from 27 to 84 was due to the utilization of active sites availing the larger surface area. This study revealed the low cost adsorbent of eucalyptus carbon may be used for removing heavy metals from ground water; as the removal of metal ions increased as contact time increases $[35,36]$.

\section{Conclusion and recommendations.}

The increase in environmental awareness and concern led to a search for new techniques capable of inexpensive treatment of polluted wastewaters with metals. The search for new technologies involving the removal of toxic metals from wastewaters has directed attention to bio-sorption, based on binding capacities of various biological materials. The heavy metals in the soil hazardous to humans include Lead, Mercury, Cadmium, Arsenic, Copper, Zinc, and Chromium. Aquatic organisms are adversely affected by heavy metals in the environment, though the toxicity is mainly a function of the chemistry of water and sediment composition in the surface water system. Many organisms can regulate the metal concentrations in their tissues. Fish and crustacean can excrete essential metals, such as Copper, Zinc, and Iron that are present in excess. Some can also excrete non-essential metals, such as Mercury and Cadmium, although this is usually met with less success. Bio-sorption is a relatively new process that has proven very promising for the removal of heavy metals from wastewater. The bio-sorption process involves a solid phase and a liquid phase containing a dissolved species to be sorbet. Due to the higher affinity of the adsorbent for the adsorbate species, the latter is attracted and bound there by different mechanisms. The process continues till equilibrium is established between the amount of solid-bound adsorbate species and its portion remaining in the solution. The degree of adsorbent affinity for the adsorbate determines its distribution between the solid and liquid phases. Process acceptance is based on the cost of the bio sorbent has to be optimum, and Cost is an important parameter, as they often are made from abundant or waste material.

\section{Acknowledgements.}

Nutrition and Food Sciences Research Centre, Tehran Medical Sciences, Islamic Azad University, Tehran-Iran as well as the Editorial Board of Labour Protection Problems in Ukraine are gratefully acknowledged.

\section{Conflicts of Interest.}

It is declared that the authors neither have any financial gain nor conflict of interests regarding this paper.

\section{REFERENCES}

1. Uddin, M.K. (2017). A review on the adsorption of heavy metals by clay minerals, with special focus on the past decade. Chemical Engineering Journal, 308, 438-462. DOI: 10.1016/j.cej.2016.09.029 77-69.

2. Khan, N.A., Ahmed, S., Vambol, S., Vambol, V., Farooqi, I.H. (2019). Field hospital wastewater treatment scenario. Ecological Questions, 30(3),

3. Vambol, S., Vambol, V., Sundararajan, M., Ansari, I. (2019). The nature and detection of unauthorized waste dump sites using remote sensing. Ecological Questions, 30(3), 43-55. DOI: 10.12775/EQ.2019.018

4. Chubenko, A.S., Kobrin, V.N., Vambol', V.V. (2013). Ekologicheski chistaya utilizatsiya otkhodov zhiznedeyatel'nosti. Otkrytyye informatsionnyye i komp'yuternyye integrirovannyye tekhnologii, (62), 98-102.

5. Vambol, S., Vambol, V., Sobyna, V., Koloskov, V., Poberezhna, L. (2018). Investigation of the energy efficiency of waste utilization technology, with considering the use of low-temperature separation of the resulting gas mixtures. Energetika, 64(4), 186-195.

6. Khan, A.H., Khan, N.A., Ahmed, S. et al. (2020). Application of advanced oxidation processes followed by different treatment technologies for hospital wastewater treatment. Journal of Cleaner Production, 122411.

7. Fick, J., Söderström, H., Lindberg, R. H., Phan, C., Tysklind, M., Larsson, D.J. (2009). Contamination of surface, ground, and drinking water from pharmaceutical production. Environmental Toxicology and Chemistry, 28(12), 2522-2527. DOI: 10.1897/09-073.1.

8. Khan, N.A., Ahmed, S., Farooqi, I.H. et al. (2020). Occurrence, Sources and Conventional Treatment Techniques for various antibiotics present in hospital wastewaters: A critical review. TrAC Trends in Analytical Chemistry, 115921.

9. Ziarati, P., Mostafidi, M., Arabian, S. et al. (2019). Patent № 138281 Ukraina, Sposib ochystky vody. Zayavka № u201904687; zayavl. 02.05.2019; opubl. 25.11.2019, Byul. № 22/2019.

10. Vambol, V.V., Shmandij, V.M., Vambol, S.O., Kondratenko, O.M. (2015). The systematic approach to solving the problem of management of eclolgical safety during process of biowaste products utilization. Ekolohichna bezpeka, (1), 7-11.

11. Shakhov, YU.V., Petukhov, Y.Y., Vambol', V.V. (2015). Matematycheskaya model' énerhotekhnolohycheskoy ustanovky dlya razdelenyya mnohokomponentnykh tazovykh smesey. Visnyk NTU «KHPI», Seriya: Matematychne modelyuvannya v tekhnitsi ta tekhnolohiyakh, 19(1128), 37-46.

12. Rezzadori, K., Benedetti, S., Amante, E.R. (2012). Proposals for the residues recovery: Orange waste as raw material for new products. Food and bioproducts processing, 90(4), 606-614.

13. Ververi, M., Goula, A.M. (2019). Pomegranate peel and orange juice by-product as new biosorbents of phenolic compounds from olive mill wastewaters. Chemical Engineering and Processing-Process Intensification, 138, 86-96. DOI: 10.1016/j.cep.2019.03.010.

14. Stavrinou, A., Aggelopoulos, C.A., Tsakiroglou, C.D. (2018). Exploring the adsorption mechanisms of cationic and anionic dyes onto agricultural waste peels of banana, cucumber and potato: adsorption kinetics and equilibrium isotherms as a tool. Journal of environmental chemical engineering, 6(6), 6958-6970

15. Motaghi, M., Ziarati, P. (2016). Adsorptive removal of cadmium and lead from oryza sativa rice by banana peel as bio-sorbent. Biomedical and Pharmacology Journal, 9(2), 739-749.

16. Razafsha, A., Ziarati, P. (2016). Removal of Heavy Metals from Oryza sativa Rice by Sour Lemon Peel as Bio-sorbent. Biomedical and Pharmacology Journal, 9(2), 543-553.

17. Tavakoli-Hosseinabady, B., Ziarati, P., Ballali, E., \& Umachandran, K. (2018). Detoxification of heavy metals from leafy edible vegetables by agricultural waste: apricot pit shell. Journal of Environmental \& Analytical Toxicology, 8(548), 2161-0525. DOI: 10.4172/2161-0525.1000548.

18. Ziarati, P., Hochwimmer, B. (2018). Reduction Nitrate Content from Contaminated Vegetable, by Hard Shell of Wild Endemic Almonds: Amygdalus lycioides and Amygdalus wendelboi. SciFed Drug Delivery Research Journal, 2, article 2.

19. Ziarati, P., Moslehishad, M., Mohammad-Makki, F.M. (2016). Novel adsorption method for contaminated water by wild endemic almond: Amygdalus scoparia. Biosciences Biotechnology Research Asia, 13(1), 147-153.

20. Pourzare, A., Ziarati, P., Mousavi, Z., Faraji, A.R. (2017). Removing Cadmium and Nickel Contents in Basil Cultivated in Pharmaceutical Effluent by chamomile (Matricaria chamomilla L.) Tea Residue. Journal of Scientific Discovery, 1(1). DOI:10.24262/jsd.1.1.17006.

21. Ziarati, P., Namvar, S., Sawicka, B. (2018). Heavy metals bio-adsorption by Hibiscus sabdariffa L. from contaminated water. Technogenic and ecological safety, 4(2), 22-32. DOI: 10.5281/zenodo.1244568. 
22. Ziarati, P., El-Esawi, M., Sawicka, B. et al. (2019). Investigation of Prospects for Phytoremediation Treatment of Soils Contaminated with Heavy Metals. Journal of Medical Discovery, 4(2), 1-16. DOI: 10.24262/jmd.4.2.19011.

23. Prasath, R.R., Muthirulan, P., Kannan, N. (2014). Agricultural wastes as a low cost adsorbents for the removal of Acid Blue 92 dye: A comparative study with commercial activated carbon. IOSR Journal of Agriculture and Veterinary Science, 7(2), 19-32.

24. Fan, Y., Yang, R., Lei, Z. et al. (2016). Removal of Cr (VI) from aqueous solution by rice husk derived magnetic sorbents. Korean Journal of Chemical Engineering, 33(4), 1416-1424. DOI: 10.1007/s11814-015-0248-y.

25. Syuhadah, N., Rohasliney, H. (2012). Rice husk as biosorbent: A review. Journal of Environmental Health, 3(1), 89-95.

26. Suemitsu, R., Uenishi, R., Akashi, I., Nakano, M. (1986). The use of dyestuff - treated rice hulls for removal of heavy metals from waste water. Journal of Applied Polymer Science, 31(1), 75-83.

27. Sihabudeen, M.M., Ali, A.A., Hussain, A.Z. (2016). Removal of heavy metals from ground water using eucalyptus carbon as adsorbent. International Journal of ChemTech Research, 9(03), 254-257.

28. Wong, K.K., Lee, C.K., Low, K.S., Haron, M.J. (2003). Removal of $\mathrm{Cu}$ and $\mathrm{Pb}$ by tartaric acid modified rice husk from aqueous solutions. Chemosphere, 50(1), 23-28.

29. Ajmal, M., Rao, R.A.K., Anwar, S., Ahmad, J., Ahmad, R. (2003). Adsorption studies on rice husk: removal and recovery of Cd (II) from wastewater. Bioresource technology, 86(2), 147-149.

30. Marshall, W.E., Wartelle, L.H., Boler, D.E., Johns, M.M., Toles, C.A. (1999). Enhanced metal adsorption by soybean hulls modified with citric acid. Bioresource Technology, 69(3), 263-268.

31. Quek, S.Y., Wase, D.A.J., Forster, C.F. (1998). The use of sago waste for the sorption of lead and copper. Water Sa, 24(3), 251-256.

32. Munaf, E., Zein, R. (1997). The use of rice husk for removal of toxic metals from waste water. Environmental technology, 18(3), 359-362.

33. Marshall, W.E., Champagne, E.T. (1995). Agricultural byproducts as adsorbents for metal ions in laboratory prepared solutions and in manufacturing wastewater. Journal of Environmental Science \& Health Part A, 30(2), 241-261. DOI: 10.1080/10934529509376198.

34. Suemitsu, R., Uenishi, R., Akashi, I., Nakano, M. (1986). The use of dyestuff - treated rice hulls for removal of heavy metals from waste water. Journal of Applied Polymer Science, 31(1), 75-83.

35. Ziarati, P., Far, B. F., Mashayekhi, E., Sawicka, B. (2019). Removing arsenic by food-processing waste (Zizyphus jujuba seeds) and study on its adsorptive properties. Technogenic and ecological safety, 5(1), 62-70. DOI: 10.5281/zenodo.2604648.

36. Khan, N.A., Ibrahim, S. (2004). Rice Husk as an Adsorbent for Heavy Metal. Proceedings of International Conference on Water and Wastewater 2004 (ASIAWATER 2004), Kuala Lumpur, Malaysia.

П. Зиарати, Д. Моради, В. Вамболь

БИОАДСОРБЦИЯ ТЯЖЕЛЫХ МЕТАЛЛОВ ИЗ ФАРМАЦЕВТИЧЕСКИХ СТОКОВ, ЗАГРЯЗНЕННЫХ ПОЧВ И ВОДЫ ПИЩЕВЫМИ И СЕЛЬСКОХОЗЯЙСТВЕННЫМИ ОТХОДАМИ: КРАТКИЙ ОБЗОР

Загрязнение почвенных и водных ресурсов тяжелыми металлами, в том числе по причине антропогенного воздействия, и как результат их токсическое воздействие на здоровье человека, является серьезной экологической проблемой последних десятилетий. Особенно актуальна проблема фармацевтических сточных вод, так как они содержат активные фармацевтические ингредиенты и широкий спектр тяжелых металлов. В то же время пищевые отходы обычно образуются на всех этапах жизненного цикла продуктов питания, а именно: в сельскохозяйственном производстве, промышленном производстве, при переработке и распределении, и даже в частных домохозяйствах. В основном пищевые отходы содержат ценные компоненты (фитохимические, белки, вкусовые соединения, полисахариды, волокна), которые могут быть повторно использованы как нутрицевтики и функциональные ингредиенты. Цель исследования - изучить потенциал пищевых и сельскохозяйственных отходов для удаления тяжелых металлов из загрязненной воды и почвы. Исследование потенциала пищевых и сельскохозяйственных отходов для удаления тяжелых металлов из загрязненной воды и почвы проводилось на основе открытых научных источников, которые были отобраны по ключевым словам, во временном интервале начиная с 2003 года или с высокой цитируемостью. Биосорбция является относительно новым процессом, который оказался очень перспективным для удаления тяжелых металлов из сточных вод. Из-за более высокого сродства адсорбента к адсорбату, последний притягивается и связывается там различными механизмами. Процесс продолжается до тех пор, пока не будет установлено равновесие между количеством твердых частиц адсорбата и его частью, остающейся в растворе. Целесообразность использования адсорбентов основана на том, что стоимость биосорбента должна быть оптимальной, так как они часто изготавливаются из постоянно образующихся в большом количестве отходов: кожура цитрусовых и граната, кожура овощей, деревянистая оболочка фруктового ядра, отходы чая и травяного чая, смесь сельскохозяйственных отходов, которые демонстрируют большой потенциал в качестве биосорбента.

Ключевые слова: тяжелые металлы; процесс биоадсорбции; сельскохозяйственные отходы; утилизация; окружающая среда. 